Нада М. Стојанчев

Основна школа „Миодраг Чајетинац Чајка”

Трстеник

Јелена С. Старчевић

Универзитет у Крагујевцу

Факултет педагошких наука у Јагодини

Катедра за друштвено-хуманистичке науке
УДК 316.624-057.874

https://doi.org/10.18485/uzdanica.2020.17.1.14

Оригинални научни рад

Примљен: 10. фебруар 2020.

Прихваћен: 11. мај 2020.

\title{
УЧЕНИЦИ МЛАЂЕГ ОСНОВНОШКОЛСКОГ УЗРАСТА У УЛОЗИ СВЕДОКА ВРШЬАЧКОГ НАСИЉА ${ }^{1}$
}

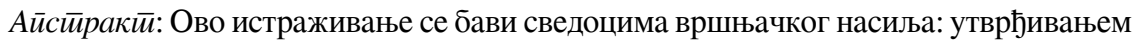
учесталости сведочења одређеним формама вршњачког насиља (вређању, оговарању и физичком насиљу), утврђивањем учесталости појединих улога које сведоци насиља могу да имају (следбеник, подржавалац, потенцијални заштитник и заштитник), као и факторима који могу да утичу на преузимање одређене улоге. Одговори ученика четвртог разреда основне школе на упитник затвореног типа показују да су релативно често у улози сведока насиља, нарочито у ситуацији вређања. Дечаци у односу на девојчице чешће преузимају улоге следбеника и подржавалаца, осим у ситуацији оговарања. На одабир улоге сведока насиља већи значај има пријатељски однос према жртви него пријатељски однос према насилном ученику.

Кључне речи: вршњачко насиље, подржавалац, следбеник, потенцијални заштитник, заштитник.

\section{УВОД}

Досадашња истраживања у области вршњачког насиља већином су насиље посматрала као дијадни процес, који се тиче искључиво насилног ученика и жртве. Како све више преовладава схватање да остали ученици из одељења имају важну улогу у процесу насиља, а могуће и пресудну улогу у погледу тога да ли ће се насиље зауставити или повећати (нпр. Попадић 2009), јавља се потреба за истраживањем учесничких улога у вршњачком насиљу. Вршњачко насиље, уз жртву и онога ко чини насиље, подразумева и велики број ученика који посматрају насиље и различито реагују на њега. Ти ученици, и када су само посматрачи, чине део сцене насиља, а нарочито када неко од њих стане у одбрану жртве или даје подршку ученику који се

${ }^{1}$ Реализацију овог истраживања финансирало је Министарство просвете, науке и технолошког развоја Републике Србије (бр. Уговора 451-03-68/2020-14/ 200140). 
насилно понаша. Реакције сведока насиља могу бити позитивне, неутралне (равнодушне) или негативне, па као такве доприносе погоршавању проблема или његовом решавању (Салмивали 2010). Ученици који су сведоци насиља могу да „награде” или да „казне” насилног ученика за његово понашање, чиме показују да ли је насилно понашање прихватљиво или није.

Проширивање оквира истраживања вршњачког насиља у смислу укључивања ученика који су у улози сведока важно је и због тога што се последице насиља и на њих одражавају. Присуствовање вршњачком насиљу повећава осећање анксиозности и аверзије према школи (Нишина, Јувонен 2005). И када нису директно укључени у насиље ученици могу да буду под његовим негативним утицајем, што омета процес учења, смањује њихову мотивацију, утиче на слабљење концентрације и подстиче изостајање из школе (Марковић 2015).

Насилне интеракције међу децом одигравају се, по правилу, пред сведоцима, било зато што су места где се дешавају јавна и на њима су присутна и друга деца, било зато што им је циљ да буду видљиве и другима. Истраживања у којима је снимано понашање деце у школском дворишту (Крејг, Пеплер 1997) и у учионици (Атлас, Пеплер 1998) показала су да се $85 \%$ насилних инцидената дешава пред вршњацима. У групи сведока насиља издвајају се они који активно помажу насилном ученику у његовим поступцима и који му се придружују (следбеник), они који пружају подршку, али не узимају учешће (подржавалац), они којима се допада оно што се догађа, али не показују отворену подршку (пасивни подржавалац), они који посматрају насиље и према њему се односе равнодушно (неукључени посматрач), који не одобравају насиље, али ништа не предузимају (потенцијални заштитник) и они који желе да разреше сукоб, да умање проблем насиља или да га зауставе (заштитник) (Олвеус, Лимбер, Михалиц 1999, према: Попадић 2009).

Понашање сведока насиља повезано је са полом. Девојчице чешће од дечака подржавају жртве, док за дечаке постоји већа вероватноћа да подстичу насилне ученике или игноришу њихово насилно понашање (Болдри 2005). У истраживању које су Трек и сарадници спровели уочено је да се дечаци чешће налазе у улогама насилника, као и асистената и подстрекача насилника, док је за девојчице карактеристично да се понашају као браниоци жртве или да се повуку из ситуација насиља (Салмивали и др. 1996).

Пријатељски односи такође имају значајну улогу у опредељивању деце да ли да бране жртву или да пружају подршку насилном ученику. Истраживање Еспелејџове, Грина и Поланина показује да је спремност да се помогне повезана са ставом према жртви (Еспелејџ, Грин, Поланин 2012). Пријатељство са жртвом могући је разлог активног заузимања за њу (Хоџис и др. 1999; Торнберг 2010) јер из блиских односа проистиче и солидарност (Хјустон, Стробе 2003, према: Билић 2013). Аналогно томе, пријатељи учени- 
ка склоних насиљу обично пружају снажну подршку ученику који се насилно понаша (Кард, Хоџис 2006).

Однос који ученици имају према насилном понашању вршњака из одељења под утицајем је још неких фактора, међу којима су структура одељења и његова неформална организација, карактеристике одељенских норми, ставови које сведоци насиља имају према насиљу, искуства претходног насиља (Болдри 2005; Марковић 2014).

\section{ПРЕДМЕТ ИСТРАЖИВАҢА}

У фокусу овог истраживања су сведоци вршњачког насиља, односно њихово понашање у ситуацијама када присуствују одређеним облицима директног и индиректног насиља и фактори који на то понашање утичу. Одабрани облици насиља су вређање или исмејавање, оговорање и ударање или гурање, док су могуће улоге сведока насиља следбеник, подржавалац, потенцијални заштитник и заштитник. Фактори избора улоге који су испитивани јесу пол, пријатељски односи сведока насиља са жртвом и пријатељски односи са учеником који се насилно понаша.

\section{МЕТОДОЛОГИЈА ИСТРАЖИВАҢА}

\section{УЗОРАК}

Узорак чине 54 ученика четвртог разреда једне основне школе од којих је 28 дечака и 26 девојчица.

\section{ИНСТРУМЕНТИ}

За прикупљање података конструисан је Уйийник за свеgоке насиља. Први део овог упитника чине три питања на којима ученици на четворостепеној скали изражавају колико су често присутвовали одређеној форми насиља од почетка школске године (тј. у протекла три месеца): никад, ретко (до три пута), понекад (једном седмично) и често (више од једном седмично). Други део упитника обухвата 11 питања на које су ученици могли да бирају одговор/е који најбоље описују њихово понашање и/или мишљење у датој ситуацији насиља, а на основу чега су сврставани у улоге следбеника, подржаваоца, потенцијалног заштитника и/или заштитника. Улога потенцијалног заштитника није понуђена једино у ситуацији оговарања.

$\mathrm{У}$ наставку је дат пример питања из другог дела упитника. 
Дешавало се да се прикључиш вређању неког ученика.

а) Да, када мој друг/другарица вређа неког ученика.

б) Да, када вређа неког са ким се не дружим.

в) Радим то онда када је забавно.

г) Не придружујем се.

\section{РЕЗУЛТАТИ ИСТРАЖИВАҢА И ДИСКУСИЈА}

Ученици који су се изјаснили да су присуствовали одабраним формама директног и индиректног насиља сведоци су вршњачког насиља и они чине 94\% испитаних ученика. Учесталост сведочења појединачним формама насиља приказана је на Графикону 1.

Графикон 1. Учесталост присуствовања вршњачком насиљу

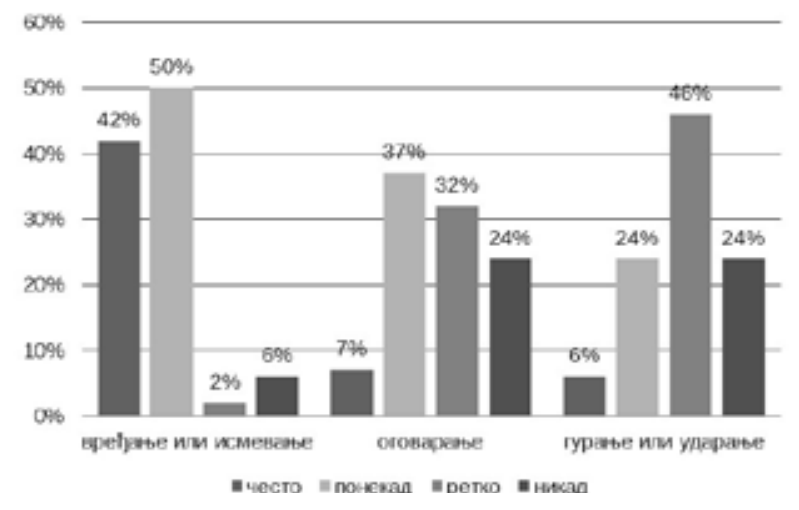

Највећи број ученика, дакле, у прва три месеца школске године нашао се у улози сведока насиља. Притом, као што се на графикону може видети, најчешће су присуствовали вређању или исмевању (42\% често, $50 \%$ понекад), потом оговарању (7\% често, $37 \%$ понекад), па најређе гурању или ударању другог ученика (6\% често, $24 \%$ понекад).

Улоге ученика у наведеним ситуацијама насиља (према самопроцени), приказане су на Графикону 2. Ученици су могли да заокруже више од једног одговора, уколико њихово понашање и мишљење није увек исто у датој ситуацији насиља, тако да бројеви на графикону показују колико је пута улога одређена одабрана (а не број ученика који ју је одабрао).

Већи ступци на десној страни графикона показују да ученици чешће бирају одговоре којима на неки начин стају уз жртву него уз насилног ученика. Сабирањем одговора по улогама, без обзира на врсту вршњачког насиља, може се израчунати да се 43 одговора (25\%) сврстава у улогу следбеника и, слично томе, 44 одговора (26\%) указује на улогу подржаваоца; већи број од- 
Графикон 2. Улоге сведока према врстама вршњачког насиља

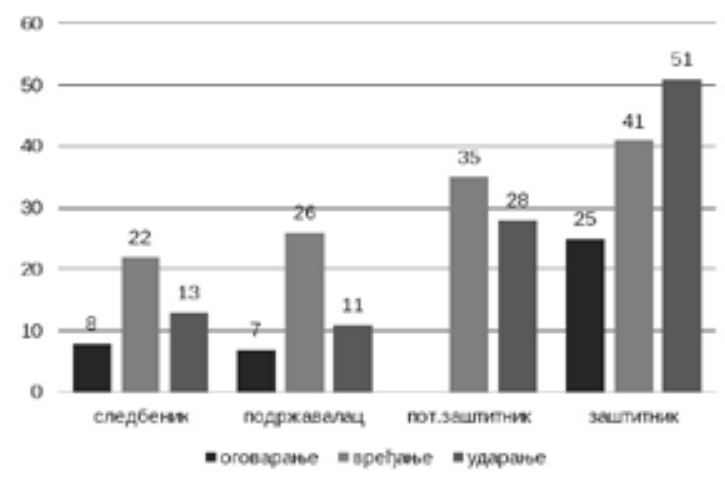

говора, њих 63 (односно 53\%), сврстава сведоке насиља у улогу потенцијалног заштитника, док 117 (63\%) одговора ученика одражава улогу заштитника. Преглед студија који је извршио Попадић (2009) показује да је спремност да се помогне доследно већа код млађих него код старијих ученика.

ПОВЕЗАНОСТ УЛОГЕ СВЕДОКА ВРШЊАЧКОГ НАСИЉА УОПШТЕ И ПОЛА УЧЕНИКА

У Табели 1 је приказано које улоге сведока су за сваку од форми насиља оирали дечаци, а које девојчице.

Tабела 1. Улоге дечака и девојчица као сведока у ситуацијама вршњачког насиља

\begin{tabular}{lcc}
\hline Следбеник & Број одговора дечака & Број одговора девојчица \\
\hline Оговарање & 2 & 6 \\
Вређање или исмевање & 16 & 1 \\
Гурање или ударање & 12 & 13 \\
Укупно & 30 & 4 \\
\hline Подржавалац & Број одговора дечака & 8 \\
\hline Оговарање & 3 & 0 \\
Вређање или исмевање & 18 & 12 \\
Гурање или ударање & 11 & 16 \\
Укупно & 32 & 16 \\
\hline Потенцијални заштитник одговора девојчица \\
\hline Вређање или исмевање & Број одговора дечака & Број одговора девојчица \\
Гурање или ударање & 19 & 32 \\
Укупно & 12 & 12 \\
\hline Заштитник & 31 & 20 \\
\hline Оговарање & Број одговора дечака & 21 \\
Вређање или исмевање & 13 & Број одговора девојчица \\
Гурање или ударање & 21 & 53 \\
Укупно & 30 & 64 \\
\hline
\end{tabular}


Дечаци имају скоро три пута више одговора који припадају улогама подржаваоца или следбеника, што је у складу са налазима претходних истраживања (Болдри 2005; Салмивали и др. 1996).

Девојчице су, у односу на дечаке, једино у ситуацији оговарања чешће реаговале као подржаваоци или следбеници, што је у складу са Попадићевом констатацијом да су „[...] девојчице окренуте афилијативним везама, па се и агресивност састоји у угрожавању тих веза” (Попадић 2009: 129). Забележено је и да девојчице више користе индиректну агресију (Лагершпец, Бјорквист, Пелтонен 1988), па самим тим и више подржавају ову врсту насиља, односно оговарање.

Улогу заштитника у ситуацијама када неког ученика оговарају или вређају подједнако преузимају и дечаци и девојчице. Дечаци су, у односу на девојчице, више у улози заштитника када неког ученика гурају или ударају. Вероватан разлог за то је страх девојчица од последица укључивања у ситуацију насиља, нарочито ако је реч о физички јачем дечаку. Већ је забележена тенденција повлачења девојчица из насилних инцидената (Салмивали и др. 1996). Тако девојчице, када је реч о физичком насиљу, нешто чешће бирају улогу потенцијалног заштитника него улогу заштитника (осуђују насиље, али не реагују).

Преглед улога сведока насиља, без обзира на врсту насиља, показује да дечаци и девојчице имају подједнак број одговора (једино) у категорији потенцијалног заштитника. Овај податак сугерише да, у погледу тога шта мисле или какав став имају према ситуацији насиља, не мора бити значајне разлике између девојчица и дечака. Разлике се појављују на плану понашања - да ли штите жртву или подржавају насилног ученика и придружују му се - и могу бити подстакнуте социјалним притисцима, који су различити за дечаке и за девојчице.

\section{ПОВЕЗАНОСТ УЛОГЕ СВЕДОКА НАСИЉА СА ПРИЈАТЕЉСКИМ ОДНОСОМ ПРЕМА НАСИЛНОМ УЧЕНИКУ И ПРЕМА ЖРТВИ}

У Табели 2 су приказани одговори испитаних ученика, сведока насиља, када су у пријатељском односу са насилним учеником и када су у пријатељском односу са жртвом.

Кард и Хоџис (Кард, Хоџис 2006) су својевремено дошли до закључка да је чест разлог пружања активне или пасивне подршке насилном ученику блиски однос са учеником који се насилно понаша. У нашем истраживању, међутим, утврђен је релативно висок проценат одговора сведока насиља који се сврставају у такве улоге и онда када насилни ученик није њихов друг или другарица (Табела 2): 53\% одговора у улози следбеника, а 75\% у улози подржаваоца. У истраживању Крејгове и Пеплерове (Крејг, Пеплер 1995) установљено је да вршњаци иначе имају знатно више поштовања и у већој 
Табела 2. Улоге сведока насиља у зависности од постојања пријатељског односа са насилним учеником и жртвом

\begin{tabular}{lcccc}
\hline Улоге & $\begin{array}{l}\text { Друг/другарица } \\
\text { насилног ученика }\end{array}$ & $\begin{array}{l}\text { Нису друг/другарица } \\
\text { насилног ученика }\end{array}$ & $\begin{array}{l}\text { Друг/другарица } \\
\text { жртве }\end{array}$ & $\begin{array}{l}\text { Нису друг/ } \\
\text { другарица жртве }\end{array}$ \\
\hline Следбеник & $20(47 \%)$ & $23(53 \%)$ & $10(23 \%)$ & $33(77 \%)$ \\
Подржавалац & $11(25 \%)$ & $33(75 \%)$ & $8(18 \%)$ & $36(82 \%)$ \\
Потенцијални заштитник & $12(21 \%)$ & $44(79 \%)$ & $36(57 \%)$ & $27(43 \%)$ \\
Заштитник & $20(29 \%)$ & $49(71 \%)$ & $60(51 \%)$ & $57(49 \%)$ \\
\hline
\end{tabular}

мери су пријатељски настројени према ученицима који се насилно понашају него према жртвама. Насилни ученици могу да уживају статус популарних, па остали ученици приклањањем насилним ученицима покушавају да обезбеде добар статус у вршњачкој групи. У најмању руку, биће додатно опрезни у преузимању заштитничких улога уколико то подразумева супротстављање популарном ученику.

Поред тога, подржавање насилног ученика може бити повезано са негативним, па и неутралним односом према жртви. Штавише, подаци које у наставку издвајамо сугеришу да је кључ конструктивног реаговања сведока насиља у њиховом односу према жртви.

Табела 2 показује да су ученици ређе следбеници и ређе подржаваоци ако су у пријатељским односима са жртвом (23\% и $18 \%$ одговора испитаних ученика) него када је насилни ученик њихов друг или другарица (47\% и $25 \%$ ). Још изразитије, ученици су много чешће потенцијални заштитници и заштитници ако је жртва њихов друг или другарица (57\% и 51\% одговора испитаних ученика) него ако су у пријатељском односу са насилним учеником (21\% потенцијалних заштитника и 29\% заштитника).

Гледано у целини, делује да у одабиру улога сведока насиља већи утицај има однос према жртви него према насилном ученику. Ово је у складу са од раније познатим чињеницама да број и квалитет пријатељстава које ученик има делују као заштитни фактор од насиља (Марковић 2014). Студија спроведена на ученицима млађег школског узраста показује да су пријатељски односи веома важан протективни фактор када је реч о виктимизацији, важнији од неповољних породичних услова (Шварц 2000). Пријатељства, нарочито са снажним и популарним пријатељима, обесхрабрују насилног ученика да врши насиље (Марковић 2014). Ако и дође до насиља, жртве могу да рачунају на помоћ и заштиту својих другова или другарица.

\section{ЗАКЉУЧАК}

У овом истраживању је потврђено да велика већина ученика присуствује ситуацијама вршњачког насиља, мада постоје значајне разлике у зави- 
сности од врсте насиља: скоро сви ученици су сведочили вређању или исмевању, око половине ученика бар једном седмично је присуствовало оговарању, а једна трећина, седмично или чешће, физичком насиљу.

Резултати испитивања показали су да сведоци насиља чешће бирају заштитничке улоге него улоге следбеника и подржавалаца, што није изненађујуће с обзиром на то да је испитиван млађи школски узраст. Притом, дечаци сведоци насиља, у односу на девојчице, преузимају активније улоге, било као заштитници, било као следбеници и подржаваоци. Коју ће од понуђених улога ученици одабрати (независно од пола) у највећој мери је зависило од односа са жртвом.

Добијени подаци могу бити од значаја за превенцију насиља. Налази најпре јасно показују да се не сме занемарити чињеница да се вршњачко насиље најчешће одвија у присуству других ученика, који различито реагују. Стратегија која би могла да има утицај на ниво насиља тиче се обезбеђивања атмосфере у одељењу у којој ниједан ученик неће бити социјално изолован. Односи у одељењу се могу испитати и путем социометријске анкете како би се на основу утврђеног стања планирало подстицање сарадње, развој међусобног разумевања, емпатије и пријатељских односа уопште.

Налази овог истраживања сугеришу да би било пожељно развијати родно осетљиве стратегије за превенцију и решавање проблема насиља. Имајући у виду да се девојчице могу плашити да отворено заштите жртву насиља, требало би питати ученике (девојчице посебно) да предложе начине који би им олакшали пријаву и свакако понудити могућност анонимне пријаве (као и у склопу праћења резултата интервенција у решавању насиља). У основи таквог деловања треба да буде стварање сигурне атмосфере у којој је учитељ, као и други запослени у школи, заинтересован и отворен за решавање проблема насиља и преноси својим деловањем поруку да се насиље неће толерисати ни над једним учеником.

С обзиром на то да су склони активном учешћу у ситуацији насиља, дечаке треба усмеравати на преузимање улога заштите и подршке, чинећи такве обрасце понашања популарним и награђујућим. Тако би било важно да се понуде ненасилни, а за дечаке привлачни мушки модели (одређени спортисти, на пример). Треба охрабривати и моделовати на конкретним примерима неприклањање понашањима са којима се не слажемо (потенцијалних заштитника је подједнак број међу дечацима и девојчицама) као индикатор независности и најпожељније врсте социјалне моћи.

Понашање сведока насиља лакше се може променити него понашање насилних ученика, стога превентивни програми са укључивањем све деце, па и сведока насиља - који се сматрају кључним у смањењу школског насиља - могу брже и успешније зауставити насиље у школама него што то могу другачије врсте стратегија. 


\section{ЛИТЕРАТУРА}

Атлас, Пеплер (1998): Rona S. Atlas, Debra J. Pepler, Observations of bullying in the classroom, The Journal of Educational Research, 92 (2), 86-99.

Билић (2013): Весна Билић, Насиље међу вршњацима: Улога бранитеља жртава, помоћника и присташа починитеља насиља те пасивних посматрача, Животи $и$ школа: часойис за йеорију и йраксу оgі̄oja и образовања, Загреб: Учитељски факултет Свеучилишта у Загребу, Хрватска, 193-209.

Болдри (2005): Anna C. Baldry, Bystander Behaviour Among Italian Students, Pastoral care in Education, 23 (2), 30-35.

Еспелејџ, Грин, Поланин (2012): Dorothy Espelage, Harold Green, Joshua Polanin, Willingness to intervene in bullying episodes among middle school students: Individual and peer-group influences, The Journal of Early Adolescence, 32 (6), 776-801.

Хоџис, Бовин, Витаро, Буковски (1999): Ernest V. E. Hodges, Michel Boivin, Frank Vitaro, William M. Bukowski, The power of friendship: Protection against an escalating cycle of peer victimization, Developmental Psychology, 35 (1), 94-101.

Кард, Хоџис (2006): Noel A. Card, Ernest V. E. Hodges, Shared targets for aggression by early adolescent friends, Developmental Psychology, 42 (6), 1327-1338.

Крејг, Пеплер (1997): Wendy M. Craig, Debra J. Pepler, Peer processes in bullying and victimization: An observational study, Exceptionality education Canada, Vol. 5, No. 3-4, 81-95.

Крејг, Пеплер (1997): Wendy M. Craig, Debra J. Pepler, Observations of bullying and victimization in the school yard, Canadian Journal of School Psychology, 13 (2), 41-59.

Лагерспец, Бјорквист, Пелтонен (1988): Kirsti M. Lagerspetz, Kaj Björkqvist, Tarja Peltonen, Is indirect aggression typical of females? Gender differences in aggressiveness in 11 to 12-year-old children, Aggressive Behavior, 14, 403-414.

Марковић (2014): Марија Марковић, Ученици као актери у превенцији вршњачког насиља у школи, Сйецијална еgукација и рехабилийација, 13 (2), 237-253.

Марковић (2015): Марија Марковић, Улоіе у вршњьчком насиљу и школски усиеех ученика (докторска дисертација), Београд: Универзитет у Београду, Филозофски факултет.

Нишина, Јувонен (2005): Adrienne Nishina, Jaana Juvonen, Daily Reports of Witnessing and Experiencing Peer Harassment in Middle School, Child Development, 76 (2), 435-450.

Попадић (2009): Драган Попадић, Насиље у школама, Београд: Инситут за психологију, УНИЦЕФ.

Салмивали (2010): Christina Salmivalli, Bullying and the peer group: A review, Aggression and violent behavior, 15 (2), 112-120.

Салмивали, Лагерспец, Бјорквист, Остерман, Каукианен (2012): Christina Salmivalli, Kirsti M. Lagerspetz, Kaj Björkqvist, Karin Österman, Ari Kaukiainen, Bullying as a group process: Participant roles and their relations to social status within the group, Aggressive Behavior, 22 (1), 1-15.

Торнберг (2010): Robert Thornberg, A Student in Distress: Moral Frames and Bystander Behavior in School, Elementary school journal, 110 (4), 585-608.

Шварц (2000): David Schwartz, Subtypes of victims and aggressors in children's peer groups. Journal of Abnormal Child Psychology, 28, 181-192. 
Nada M. Stojančev

Elementary school "Miodrag Čajetinac Čajka"

Trstenik

Jelena S. Starčević

University of Kragujevac

Faculty of Education

Department for Human Sciences

\section{LOWER ELEMENTARY SCHOOL STUDENTS IN A ROLE OF PEER VIOLENCE WITNESSES}

Summary: The paper deals with witnesses of peer violence: determining the frequency of witnessing to particular forms of peer violence (insulting, gossiping and physical violence), determining the frequency of specific roles that witnesses of violence may have (assistant, reinforcer, potential defender and defender), as well as factors which may affect the roles of witnesses. The responses of fourth-grade elementary pupils to the closed-ended questionnaire reveal that pupils relatively often witness violence, especially in the case of insulting. Boys are more likely to assume the roles of followers and supporters than girls do, except in a gossip situation. A friendly relationship with a victim of violence is more important for the choice of a role than a friendly relationship with a violent student.

Keywords: peer-violence, assistant, reinforcer, potential defender, defender. 